\title{
Universals of Prenasalized Consonants: Phonemic or Derived, Single or Complex?
}

\author{
Jin-young Tak \\ Sejong University
}

\begin{abstract}
Most previous research on prenasalized consonants (Herbert 1975, 1977, 1986; Hayes 1991; Hyman 1992) focuses mainly on those derived from two underlying segments and functioning as a unitary segment. However, by examining further data from various languages, this paper proposes that in fact there are four types of prenasalized consonants: phonemic prenasalized consonants as in Fijian, derived prenasalized consonants functioning as a unitary segment as in Kikuyu, derived prenasalized consonants that behave as a complex segment as in Japanese, and phonetically enhanced prenasalized consonants as in Southern Barasano. Additionally, this paper compares phonologically driven prenasalized consonants to morphologically driven ones, arguing that in most cases phonologically
\end{abstract}

\footnotetext{
* I would like to express my genuine gratitude to the three anonymous reviewers of this journal for their valuable comments. All errors and misrepresentations are the author's responsibility.
}

Jin-young Tak

Department of English Language and Literature, Sejong University

98 Gunja-dong, Gwangjin-gu, Seoul 143-747 Korea

Phone +82-(0)2-3408-3637; Email: jytak@sejong.ac.kr

Received July 10, 2011; Revised August 31, 2011; Accepted September 9, 2011. 
driven consonants are developed into a single segment, while in a number of the languages the morphologically driven nasal-plusconsonant sequences turn out to be sequences of a syllabic nasal and a consonant (i.e., NC). Furthermore, based on the typology of prenasalized consonants, this paper argues that phonetic adjustments, such as vowel lengthening or duration of prenasalized consonants, cannot be a cue in deciding their phonemic or phonetic status since some Bantu languages, wherein prenasalized consonants are derived from underlying two segments, behave as a singleton and do not lengthen a preceding vowel. Finally, this paper proposes that irrespective of their diverse realizations, there is only one underlying representation $\mathrm{NC}$, and their distributions can be accounted for in a uniform way based on the roles of universal constraints such as Align-Root-Left, Uniformity, Max- $\mu,{ }^{*}$ Complex, and ${ }^{*}$ Coda within the framework of Optimality Theory (McCarthy \& Prince 1986)

Keywords: prenasalized consonants, typology, synchronic analysis, language family, optimality theory, alignment constraints

\section{Introduction}

This paper investigates distributions and phonological representations of prenasalized consonants (i.e., ${ }^{\mathrm{N}} \mathrm{C}$ ) in comparison with sequences of a nasal and a consonant (i.e., N.C). ${ }^{1}$ Chomsky \& Halle (1968: 317) describe prenasalized consonants as follows:

(1) Prenasalized consonants differ from the more usual type of nasal consonant in that the velum, which lowered during the period of oral occlusion, is raised prior to the released of the occlusion, whereas in the more common type of nasal consonant, the velum is raised simultaneously with or after the release of the oral occlusion.

\footnotetext{
1 The symbol period (.) refers to a syllable boundary.
} 
Because of a strikingly brief nasal onset period, prenasalized consonants are regarded as a single segment; they are treated differently from nasal-plus-consonant sequences (i.e., N.C) in which the nasal is part of the preceding syllable (either coda or syllabic consonant), while the consonant is an onset of the following syllable. This observation relies on their unique distributions in which they can occur in positions where clusters cannot. In Fijian and some other Pacific languages where there is a gap of voiced consonants in their phonetic inventory, prenasalized consonants occur where voiced stops may occur, and they behave as underlying single segments (Milner 1956).

However, based on compensatory lengthening of the preceding vowel of prenasalized consonants, Herbert (1975, 1977, 1986), Hayes (1991), and Hyman (1992) propose that in fact prenasalized consonants do not occur at the level of the underlying representation. Rather, they are phonetic manifestations derived from underlying clusters, triggering phonetic adjustments, such as vowel lengthening or nasal shortening. Therefore, from their analyses, prenasalized consonants are phonetic sequences of a nasal followed by a consonant, which function unitarily as a single segment (Herbert 1975, 1977). In many languages in Africa, South America, South Asia, New Guinea, and the Pacific, prenasalized consonants behave as a single unit, derived from underlying nasal-plus-obstruent sequences over a morpheme boundary or within a morpheme (Odden 1996). Especially, as revealed by Arnott (1970) and Wiswall (1989), Fula, one language of the Niger-Kordofanian family spoken in Senegambia and Guinea to Cameroon and Sudan, has prenasalized consonants derived from the floating feature [nasal], behaving as a single segment. Further, they contrast with clusters as seen in $\left[{ }^{\mathrm{m}} \mathrm{b}\right]$ and $\left[\mathrm{m}^{\mathrm{m}} \mathrm{b}\right]$ in the intervocalic position.

However, this paper proposes that the distributions of the prenasalized consonants cannot be defined in so simple a manner. In fact, there is more than one type of prenasalized consonants cross- 
linguistically. Depending on the language, their representations vary. They may contrast with a single consonant in the underlying representation, they may be derived from underlying nasal-consonant sequences, behaving either as a single unit or a complex segment, or they may occur as a cluster rather than a single unit usually over a morpheme boundary, contrasting consonant clusters. Based on this assumption, this paper collects the relevant data based on the classification of Ruhlen (1987) in order to define the nature of prenasalized consonants and then classifies languages into the four following types: ${ }^{2}$

(2) Language Classification

a. Type I: Fujian

Prenasalized consonants $\left({ }^{\mathrm{N}} \mathrm{C}\right)$ contrast with single segments and therefore have the same phonotactic distributions as single segments do.

b. Type II: Kikuyu

Prenasalized consonants $\left({ }^{\mathrm{N}} \mathrm{C}\right)$ are derived through the application of phonological rules (i.e., fusion of nasalplus-consonant clusters or [nasal]-spreading), behaving like single segments.

c. Type III: Japanese

Prenasalized consonants $\left({ }^{\mathrm{N}} \mathrm{C}\right)$ are derived but contrast with ordinary clusters of a homorganic nasal and a following obstruent (NC), behaving as complex segments.

d. Type IV: Southern Barasano

Prenaslized consonants are not phonological entities, but

2 There is no question of prenasalized consonants in many languages. However, English only allows NC sequences word-finally or -medially. Medial N and C sequences are heterosyllabic as in content [kən.tænt]. Additionally, Diola-Fogny, spoken in Gamiba and Senegal, allows only NC sequences where initially nasals are syllabic and medially $\mathrm{N}$ and $\mathrm{C}$ are heterosyllabic. In this paper, the languages permitting only NC clusters, like English, are excluded. 
phonetic realizations enhanced by articulatory adjustments.

This paper is organized as follows. Section 2 examines data on prenasalized consonants by their geography and discusses their characteristics. Section 3 provides an optimality-theoretic account of prenasalized consonants. Section 4 offers a conclusion and further remarks on this paper.

\section{The Distributions of Prenasalized Consonants}

It has been reported that there are over 100 language families in the world including Indo-European, Uralic, Altaic, Sino-Tibetan, Malayo-Polynesian, Afro-Asiatic, Caucasian, Dravidian, Austroasiatic, Niger-Congo, and so on (Ruhlen 1987). This paper groups major language families based on their geography (i.e., Africa, Europe, Oceania, East Asia, South Asia, North America, and South America) and analyzes them in terms of the distributions of prenasalized consonants. Among these language families, those allegedly argued to have prenasalized consonants are investigated in this paper.

\subsection{Africa}

Afroasiatic, Nilo-Saharan, and Niger-Congo are the three largest language families in Africa, followed by the various small families (i.e., Indo-European, Austroneasian, and Khoisian) assumed that originated outside Africa (Welmers 1978, Ruhlen 1987).

Many Niger-Congo languages have units consisting of a nasal followed by a homorganic oral consonant in word-initial positions (i.e., either N.C or ${ }^{\mathrm{N}} \mathrm{C}$ ). In Gur and Kwa languages, nasals in such cases are syllabified as a separate syllabic segment (i.e., N.C) $;^{3}$ in

\footnotetext{
3 There are 45 languages in Kwa, a branch of the Niger-Congo language family, in
} 
many Bantu languages, these sequences are analyzed as unitary prenasalized consonants (i.e., ${ }^{\mathrm{N}} \mathrm{C}$ ). Bantu is one of the language families, full of prenasalized consonants as indicated in its name (i.e., $n t$ in bantu, ba 'noun prefix for Class 2' and $n t u$ 'people'). What is in common is that prenasalized consonants in Bantu are not defined as a phonological category; instead, they are assumed to be derived from two underlying segments, behaving a single unit. However, they pattern differently in different languages. For example, in many Bantu languages, such as Kilega, spoken in Congo, prenasalized consonants are analyzed as unitary segments that can occur word-initially and intervocalically; the unification of the underlying NCs does not trigger vowel lengthening. This is illustrated in (3).

(3) Kilega (Tak 2006)

a. Word-initial

/N-pene/ [ ['pe.ne $] \quad$ 'a goat' noun class 9 prefix-goat

/N-ko-sond-a/ [ $\quad{ }^{\mathrm{p}}$ ko.so. $\left.{ }^{\mathrm{n}} \mathrm{da}\right] \quad$ 'I taste' $1^{\text {st }}$ singular subject prefix-present tense-taste-final vowel

b. Word-internal

\begin{tabular}{|c|c|}
\hline $\begin{array}{l}\text { /mv-ntu/ }\left[\mathrm{mv} .{ }^{\mathrm{n}} \mathrm{tu}\right] \\
\text { noun class } 1 \text { prefix-people }\end{array}$ & 'a person' \\
\hline $\begin{array}{l}\text { /ba-ntu/ } \quad\left[\text { ba. }{ }^{n} \text { tu }\right] \\
\text { noun class } 2 \text { prefix-people }\end{array}$ & 'people' \\
\hline $\begin{array}{l}\text { /ku-kamb-a/ } \\
\text { to-labor-final vowel }\end{array}$ & 'to labol \\
\hline
\end{tabular}

By contrast, in some languages, such as Luganda, spoken mainly

the southern area of Ghana, Togo, Benin, Nigeria, and Côte d'Ivoire. Gur also belongs to the same Niger-Congo language family with 70 languages spoken in the northern part of Ghana, Togo, Côte d'Ivoire, Benin, and southwestern Niger (Ruhlen 1987). 
in the Buganda region of central and southern Uganda, word-initial prenasalized consonants are not permissible; word-initial NCs are not unified as prenasalized consonants, and the preconsonantal nasal becomes syllabic (i.e., N.CV), as shown in (4a). However, morpheme-internal NCs are always realized as prenasalized consonants, triggering vowel lengthening (Herbert 1975, Clements 1986, Hubbard 1995b). This is shown in (4b).

(4) Luganda (Tak 2006)
a. /N-kuba/
[n.ku.ba]
'rain' noun class 9 prefix-rain
/N-dab-a/ [n.da.ba] 'I see'
$1^{\text {st }}$ singular subject prefix-see-final vowel
b. /mu-ntu/
[muu. ${ }^{\mathrm{n}} \mathrm{cu}$
'a person'
noun class 1 prefix-people

/ba-ntu/ [baa. ${ }^{\mathrm{n}}$ tu] 'people'
noun class 2 prefix-people

$/ \mathrm{ku}-$ lind-a/
to-wait-final vowel

In most Niger-Kongo languages, prenasalized consonants are the real phenomena; their realizations vary depending on given languages. Interestingly, prenasalized consonants do not always trigger vowel lengthening as in (3), which is regarded as strong evidence supporting their derived status. Additionally, some nasal morphemes (i.e., -N-) do not participate in deriving prenasalized consonants; rather, they surface as a syllabic nasal as in (4a). To account for these, Odden (1996) assumes that the coda nasals are not moraic in Kilega, and so deriving prenasalized consonants do not lengthen the preceding vowel, as illustrated in (5a). In contrast, the coda nasal should be treated as moraic if prenasalized consonants condition vowel lengthening as in Luganda (Hayes 1989, Odden 1996). This is seen in (5b). 
(5) Prenasalized Consonants and Vowel Lengthening

a. /ba-ntu/ $\rightarrow\left[\right.$ ba. ${ }^{n}$ tu] 'people' in Kilega

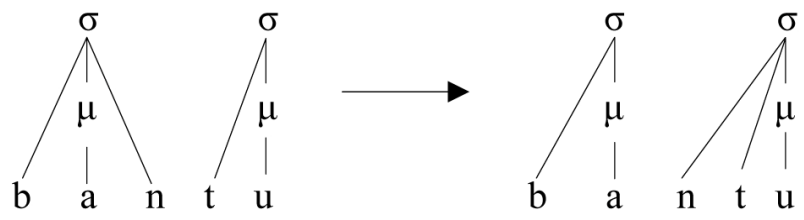

b. /ba-ntu/ $\rightarrow$ [baa. ${ }^{\mathrm{n}}$ tu] 'people' in Luganda

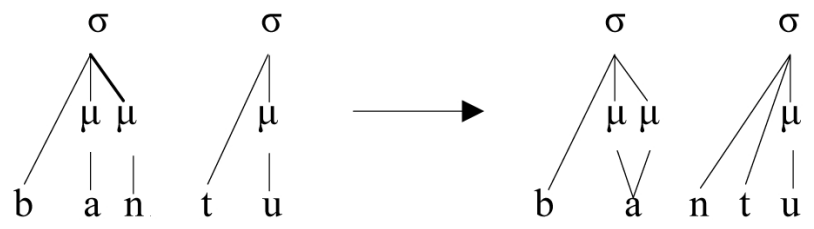

On the other hand, in example (4a), the nasal part of nasal-plusobstruent sequences is realized as syllabic. Following Hyman \& Ngunga (1997) and Odden (1996), this paper proposes that they are originally derived from a nasal followed by a vowel (i.e., NV or Proto-Bantu ${ }^{*} \mathrm{NV}$ ) and have to keep the syllabicity of their origins.

\subsection{Europe}

The Indo-European and Uralic are the largest language families spoken in Europe; there are several minor language families such as Turkic, Monglian, Basque, and Georgian. Little research has been reported on the occurrence of prenasalized consonants in languages spoken in Europe; rather, restrictions of NC sequences in marginal positions are the main theme. For example, in Spanish, wordinternal NCs are highly restricted. Only heterosyllablic clusters consisting of homorganic sounds are allowed due to articulatory conditions; /mb/ and or /nd/ is permissible, while ${ }^{*} / \mathrm{md} /$ or ${ }^{*} / \mathrm{nb} /$ are not (Harris 1969). By contrast, in German, the internal $/ \mathrm{md} /$ is 
$\begin{array}{lll}\text { (7) Underlying Form } & \text { Surface Form } & \text { Gloss } \\ \text { a. } / \text { kuNTa-NTu/ } & \left(\mathrm{ku}^{\mathrm{n}} \mathrm{da}\right)(\mathrm{tu}) & \text { 'he/she/it sleeps' } \\ \text { b. } / \text { koNTu-NTu/ } & \left(\mathrm{ko}^{\mathrm{n}} \mathrm{du}\right)(\mathrm{tu}) & \text { 'he/she/it carries' }\end{array}$

In examples in (7), the present tense $3^{\text {rd }}$ person singular suffix /-NTU/ occurs foot-initial, the underlying ghost nasal is not surface. However, it makes the previous syllable closed; the preceding NT is realized as a prenasalized $\left[{ }^{n} \mathrm{~d}\right]$.

\subsection{South America}

Spanish and Portuguese are the most spoken languages in South America, followed by other official languages such as Dutch, English, French, and Arabic. Also, there are several indigenous languages such as Quechua spoken in Ecuador, Peru, Chile, and Argentina (Ruhlen 1987).

Terena, an Arawakan language of South American in Brazil, also displays prenasalized consonants. The first person form is realized through the nasalization of the stem, starting at the left edge and extending until the first stop or fricative, which is realized as prenasalized (Cole \& Kissebert 1994, 1995).
(8) $3^{\text {rd }}$ Singular Subject
$1^{\text {st }}$ Singular Subject
Gloss
a. piho
mbiho
'went'
b. otopiko
$\tilde{o}^{\text {n }}$ dopiko
'chopped'
c. simoa
nzimoa
'came'
d. omo
õmõ
'carried'

Prenasalized stops can occur word-initially. However, it is doubtful whether prenasalized consonants are phonemic or not, solely based on the data in (8). In this language, a morpheme for the $1^{\text {st }}$ singular is the feature [nasal]; this feature aligned to the left edge of the stem spreads to the right. The interesting characteristic of the 
Terena system is that nasals are transparent in terms of nasal spreading, while obstruents are opaque, deriving prenasalized consonants (Cole \& Kisseberth 1994, 1995). Given this, the present paper proposes that prenasalized consonants in Terena, which can be morphologically defined, do not present in the underlying representation; rather, they are morphologically-driven entities.

In Land Dayak (Scott 1964, Coffman 2008), nasal consonants nasalize the following vowel. If nasal consonants occur at the end of the word following a vowel, they are replaced by a prenasalized stop.

Apinayé is a language spoken in central Brazil, where prenasalized consonants are derived from homorganic nasalobstruent sequences over a syllable boundary, functioning as a single unit (Ham 1961, Burgess \& Ham 1968, Coffman 2008). In this language, the underlying homoragnic consonant clusters over a syllable boundary are subject to simplification, lengthening a preceding vowel, while heterorganic consonant sequences are allowed over the syllable boundary (Coffman 2008: 192). This is seen in (9).

(9) Consonant Clusters over a Syllable Boundary
a. $/ \mathrm{t} \varepsilon \mathrm{p}+\mathrm{pič} /$
[te:pič]
'just fish'
b. $/ \mathrm{t} \varepsilon \mathrm{p}+\mathrm{m} \varepsilon \check{\mathrm{c}} /$
$[\mathrm{t} \varepsilon: \mathrm{m} \varepsilon \check{\mathrm{c}}]$
'good fish'
c. /t\&p+vər/
$[\mathrm{t} \varepsilon: \mathrm{v} r]$
'to fish'

Interestingly, homorganic nasal-obstruent sequences over the syllable boundary create prenasalized consonants, instead of simplification, triggering compensatory lengthening of the preceding vowel. This is contrary to Coffman (2008) who treats homorganic nasal-obstruent sequences as a cluster instead of a single prenasalized consonant. However, due to the fact that homorganic nasal-obstruents undergo the same phonological process, vowel lengthening as homorganic consonant clusters do after simplification, this paper argues that prenasalized consonants are a unitary segment derived 
from two underlying segments. This is shown in (10).

(10) Derived Prenasalized Consonants
a. /tom+pič/
[to: ${ }^{\mathrm{m}}$ pič $]$
'just frekle'
b. /men+ža/
[me: $\left.{ }^{n_{\mathrm{Z}} \mathrm{a}}\right]$
'this honey'

The data in (9) and (10) clearly support that in Apinayé prenasalized consonants are derived segments from underlying homorganic clusters; they behave as unitary segments like a single consonant.

In Southern Barasano, prenasalized consonants occur as variants of nasals before oral vowels (Gudschinsky et al. 1970). In this language, the voiceless stops and fricatives have no nasal counterparts. In contrast, the other consonants have nasal counterparts as in $[\mathrm{w} \sim \tilde{\mathrm{w}}], \quad\left[{ }^{\mathrm{m}} \mathrm{b} \sim \mathrm{m}\right], \quad[\mathrm{r} \sim \tilde{\mathrm{r}}]$; it is assumed that the occurrence of prenasalized consonants in words such as [ $\left.{ }^{\mathrm{n}} \mathrm{drio}\right]$ 'fly' and [wa ${ }^{\mathrm{m}} \mathrm{ba}$ ] 'come!' is totally predictable. In other words, nasal consonants are always followed by nasalized vowels, while prenasalized consonants are followed by oral vowels. Therefore, it is assumed that in this language there are two types of words: nasal words that are lexically marked by a ghost [+nasal] and oral words that are lexically unmarked by this feature (Gudschinsky et al. 1970). This is seen in (11).

(11) [+nasal] Lexicon
a. mãnõ
'none'
b. mĩnĩ
'bird'
juka
'vulture'
c. mãก̃ãrĩ
'comer'
wati
'going?'
d. ఇãmõrõ nĩ 'ear'
${ }^{\mathrm{m}} \mathrm{ba}{ }^{\mathrm{n}} \mathrm{go}$
'eater'
ho"goro 'butterfly'

[-nasal] Lexicon

According to Piggott (1992), prenasalization is enhanced by the articulatory adjustments required to achieve spontaneous voicing. As for oral voiced stops, it is difficult to maintain airflow through the subglottal area since the supraglottal cavity is closed to articulate 
them. To maintain air pressure across the glottis, air is allowed to escape through the nasal cavity, so that speakers can prevent air pressure from building up in the supraglottal cavity. Based on the proposal of nasal leakage, the prenasalized stops are not phonologically nasal at all, while phonologically, they are fully "oral."

\subsection{Oceania}

The Austronesian family is the most common in Oceania. This family includes approximately 1,000 languages, spoken by about 250 million speakers. Malay and Indonesian account for about 140 million; other dominant languages include Tagalog in the Philippines, the aboriginal languages of Formosa and the many languages of the Pacific Islands, from Hawaiian in the north Pacific to Maori in New Zealand (Ruhlen 1987).

Like Bantu languages, many Austronesian languages possess prenasalized consonants; however, some of Austronesian languages are assumed to be a single phoneme, different from the ones in Bantu, which are derived from two underlying segments. For example, Fijian, an Austronesian language of the Malayo-Polynesian family spoken in Fiji, displays the unitary behavior of prenasalized consonants. ${ }^{6}$ In this language there are a series of voiceless stops, [p, $\mathrm{t}, \mathrm{k}]$. Interestingly, there are a series of prenasalized stops, $\left[{ }^{\mathrm{m}} \mathrm{b},{ }^{\mathrm{n}} \mathrm{d}\right.$, $\left.{ }^{\mathrm{n}} \mathrm{g}\right]$; the voiced stops, [b, d, g], are not permissible. ${ }^{7}$ Additionally, Fijian does not allow word-initial consonant clusters; however, prenasalized consonants appear in this position. Based on their given distributions, it has been argued that prenasalized consonants and a single consonant are contrastive and occur underlyingly. Consider the phonetic experiments on the duration of prenasalized and single

\footnotetext{
6 There are 450,000 Fijian speakers who use it as a first language in addition to 200,000 second-language speakers (Ruhlen 1987).

7 The sound [p] occurs only in loanwords in Fijian.
} 
consonants in the medial positio (Maddieson 1989).

(12) Duration of Prenasalized and Single Consonants

\begin{tabular}{|c|c|c|c|}
\hline${ }^{\mathrm{N}} \mathrm{C}$ & Mean & $\mathrm{C}$ & Mean \\
\hline$/{ }^{\mathrm{m}} \mathrm{b} /$ & 132 & $/ \mathrm{t} /$ & 125 \\
\hline$/{ }^{\mathrm{n}} \mathrm{d} /$ & 131 & $/ \mathrm{k} /$ & 116 \\
\hline$/{ }^{\mathrm{n}} \mathrm{g} /$ & 113 & $/ \mathrm{l} /$ & 117 \\
\hline
\end{tabular}

The similar experiment on the duration measurement of Swahili initial prenasalized consonants done by Welmer (1978) also adduces that single consonants and prenasalized consonants are similar in terms of their duration.

Furthermore, in Fijian the fact that prenasalized consonants do not condition lengthening of the preceding vowel supports the view that prenasalized consonants in some languages like Fijian are a singleton (Maddieson 1989).

(13) Duration of a Vowel before Prenasalized Consonants

\begin{tabular}{|c|c|c|c|c|c|}
\hline $\mathrm{V}^{\mathrm{N}} \mathrm{C}$ & & Mean & $\mathrm{VC}$ & & Mean \\
\hline /_nd/ & $\mathrm{ka}^{\mathrm{n}} \mathrm{da},{ }^{\mathrm{n}} \mathrm{da}^{\mathrm{n}} \mathrm{da}$ & 139 & /_t/ & ${ }^{\mathrm{n}}$ drata, mo ${ }^{\mathrm{n}}$ drata & 142 \\
\hline /_ng/ & ${ }^{\mathrm{g}} \mathrm{ga}^{\mathrm{n}} \mathrm{ga}$ & 148 & /_k/ & ${ }^{\mathrm{m}}$ baka, na ${ }^{\mathrm{m}}$ baka & 130 \\
\hline /_mb/ & $\mathrm{ka}^{\mathrm{m}} \mathrm{ba}$ & 141 & $/ / \mathrm{l} /$ & ${ }^{\mathrm{n}}$ dala & 142 \\
\hline
\end{tabular}

As seen in tableau (13), Fijian vowels are rarely affected by following consonants, supporting the idea that prenasalized consonants are single segments exclusively belonging to the onset. Prenasalized consonants neither lengthen nor shorten the duration of the preceding vowel. Furthermore, they do not have the longer duration themselves compared to a single consonant. Therefore, prenasalized consonants, in languages like Fijian, which has no effect on the preceding vowel duration, are assumed to be 
contrastive with an underlying single consonant.

It is reported that prenasalized consonants in Tok Pisin, a creole spoken in northern mainland Papua New Guinea and the New Guinea Islands, are derived from underlying voiced consonants (http://en.wikipedia.org/wiki/Prenasalized_consonant). In contrast to Fijian, the prenasalized consonants in Tok Pisin are a phonetic manifestation of voicing rather than a separate phoneme. For example, many speakers of Tok Pisin pronounce the preposition bilong (originally from English belong), standing for 'of, from, for,' as pronounced [ ${ }^{\mathrm{m}}$ bilon]. ${ }^{8}$ Given this, this paper assumes that the prenasalized consonant in Tok Pisin is a single segment achieved in low-level phonology.

Furthermore, it has been reported that Australian languages exhibit prenasalized consonants (Evans 1995). ${ }^{9}$ Whether they should be treated as phonemic or derived is still debatable since they also furnish many instances of consonant clusters (i.e., a nasal coda followed by an onset consonant, N.C). Alawa, spoken in Roper River in the Northern Territory, contrasts prenasalized consonants with nasal-plus-stop sequences. In this language, sequences of a nasal and a consonant over a morpheme boundary are treated as two different segments in such a way that a nasal is classified as a coda, and a stop as an onset of the following syllable.

By contrast, Nash (1979) analyzes Yidin ${ }^{\mathrm{y}}$ as a language that contains prenasalized consonants as a phoneme since they occur word-initially. However, Dixon (1977) proposes that in Yidin ${ }^{\mathrm{y}}$ prenasalized consonants are realized phonetically as simple stops

\footnotetext{
${ }^{8}$ In the name of Tok Pisin, tok means 'word' or 'speech' as in 'talk,' and pisin means 'pidgin' (http://en.wikipedia.org/wiki/Tok_Pisin).

9 The Arrernte languages, spoken in and around Alice Springs in the Northern Territory has both prenasalized consonants and NC clusters, but does not have any other word-initial consonant clusters, for example, ["tange] 'flour seed,' [mpenge] 'riped, cooked.' Interestingly, this language displays preconsonantal nasals, as illustrated in [p $\mathrm{p}^{\mathrm{m}}$ wa๘ə] 'coolamon' (Berry 1998).
} 
word-initially and as nasal stop clusters elsewhere.

Ladefoged \& Maddieson (1996) argue that in Austronesian and Australian languages prenasalized consonants do not lengthen a preceding vowel on opposition to a general assumption that prenasalized consonants lengthen a preceding vowel. However, what they fail to capture in these languages is that, in fact, prenasalized consonants are contrastive in the underlying representations, implying that they are phonemes so that any phonetic adjustments are not required. Therefore, the non-applicability of vowel lengthening in Austronesian and Australian languages should not be treated in the same manner as in Bantu languages.

\subsection{East Asia}

Languages spoken in East Asia, Chinese, Japanese, Korean, and Vietnamese, have been greatly influenced by Classical Chinese. It has been reported that, in some of the Tohoku dialects, spoken in northeastern Japan, prenasalized stops $\left[{ }^{\mathrm{n}} \mathrm{g},{ }^{\mathrm{n}} \mathrm{dz},{ }^{\mathrm{n}} \mathrm{d},{ }^{\mathrm{m}} \mathrm{b}\right]$ exist, derived by nasal insertion whereby underlying voiced stops are prenasalized, as seen in (14). However, the data in (15), unlike the data in (14), no nasal is epenthesized before intervocalic [d] and [g], derived by obstruent voicing.

(14) Nasal Insertion (Kanai 1982)
a. $/$ hada/ $\rightarrow \quad\left[\mathrm{ha}^{\mathrm{n}} \mathrm{da}\right]$
*[handa]
'skin'
b. $/$ mado/ $\rightarrow \quad\left[\mathrm{man}^{\mathrm{n}} \mathrm{do}\right]$
*[mando]
'window'
c. $/$ mada $\rightarrow \quad\left[\mathrm{ma}^{\mathrm{n}} \mathrm{da}\right] *[$ manda $]$
'still'
d. $/ \mathrm{kag}$
[kaygi]
$\rightarrow \quad[$ kayi $]$
'key'
e. /kagu/
[kgygu]
$\rightarrow$
[kayu
'tell'
f. /sugu/
[suygu]
$\rightarrow \quad$ sunu $]$
'soon'

(15) No Nasal Insertion
a. /hata/
[hada] *[ha $\left.{ }^{\mathrm{n}} \mathrm{da}\right]$
'flag' 


$\begin{array}{llll}\text { b. } / \mathrm{mato} / & {[\text { mado }]} & *\left[\mathrm{ma}^{\mathrm{n}} \mathrm{do}\right] & \text { 'target' } \\ \text { c. } / \text { ito/ } & {[\text { ido }]} & *\left[\mathrm{i}^{\mathrm{n}} \mathrm{do}\right] & \text { 'tread' } \\ \text { d. } / \text { kaki/ } & {[\text { kagi }]} & *[\text { kani }] & \text { 'permission' } \\ \text { e. } / \mathrm{kaku} / & {[\text { kagu }]} & *[\text { kayi }] & \text { 'write' } \\ \text { f. } / \text { suku/ } & {[\text { sugu }]} & *[\text { suyu }] & \text { 'like' }\end{array}$

The data in (14) and (15) show that prenasalized consonants are not phonemes, but derived segments applied by a phonological rule inserting a homorganic nasal before the underlying intervocalic /d/ and $/ \mathrm{g} /$. Particularly noticeable is that the underlying $/ \mathrm{g} /$ is realized as $[\mathrm{y}]$ in the surface form as in (14d-f) where a nasal is inserted and the trigger $/ \mathrm{g} /$ is deleted, which strongly supports the view that prenasalized consonants function as a complex segment so that only the underlying /g/ is applicable to deletion. If prenasalized consonants were ever a single segment, the deletion of part of the prenasalized consonants was not plausible. Contrary to Kanai (1982), YamaneTanaka (2005) argues that at least in this dialect prenasalized stops are phonemes not allophonic, providing minimal pairs such as /mado/ 'target' vs. /ma do/ 'window,' /hada/ 'flag' vs. /ha ${ }^{\mathrm{n}} \mathrm{da} /$ 'skin.' However, this paper abandons Yamane-Tanaka's proposal and adopts Kanai (1982) assuming that the underlying form of the word 'target' is /mato/, rather than /mado/ because of the well-documented rule Obstruent Voicing in Japanese.

However, underlying nasals before consonants or the word boundary are realized as a coda of the preceding syllable, being moraic. This is seen in (16) from Kanai (1982).

(16) Moraic Nasals in Japanese
a. /hon/
[hon]
'book'
b. /hontou/
[honto]
'real'
c. /hondou/
[hondo:]
d. /indo/
[indo]
'main building'
'India' 
The data in (16) differ from that in (14) in such a way that nasals derived by nasal insertion become part of prenasalized consonants, while underlying nasals are syllabified as the coda of the preceding syllable.

Based on the data in (14), (15) and (16), this paper proposes that the Tohoku dialects in Japan are of Type III, wherein prenasalized consonants contrast nasals followed by homorganic obstruents, functioning as complex segments.

In addition, prenasalized consonants are widely used in Loloish languages of Tibeto-Burman family, such as Yi and Naxi, spoken in southern China. Also, the prenasalized consonants, occur in several branches of the Hmong-Mien language family of Southern China such as Mong Leng, spoken in the highlands of Laos, Thailand, and Vietnam (Bruhn 2006).

\subsection{South Asia}

In South Asia, several hundred languages are spoken, belonging to either the Indo-European, the Dravidian, the Austroasiatic, or the Tibeto-Burman families. ${ }^{10}$ Many of the Austroasiatic and the Tibeto-Burman families exhibit prenasalized consonants. Sinhalese, an Indo-European language spoken in Sri Lanka, contrast prenasalized consonants with heterosyllabic NCs, which implies that prenasalized consonants are phonemic. Consider the following data supporting the phonemic status of prenasalized consonants in this language.

(17) Singular Definite Formative (Feinstein 1979)
a. kadə
'shoulder pole'
b. kanə
'ear'
c. $\mathrm{ka}^{\mathrm{n}} \mathrm{d} \partial$
'trunk'
d. kandə
'hill'

${ }^{10}$ Refer to $<$ http://en.wikipedia.org/wiki/Languags_of_South_Asia $>$. 
The examples in (17) show that a prenasalized consonant and a sequence of NC clusters are contrastive, resulting in the different meaning. The difference between data (17c) and (17d) depends on where the syllable boundary occurs: [ka. $\left.{ }^{\mathrm{n}} \mathrm{d} ə\right]$ and [kan.də], respectively. ${ }^{11}$

In Sinhalese, some nouns exhibit root-final geminate consonants in the singular but single consonants in the plurals, as shown in (18).

(18) Inanimate Nouns in Sinhalese ${ }^{12}$

$\begin{array}{lll}\text { Singular } & \text { Plural } & \text { Gloss } \\ \text { a. pottə } & \text { potu } & \text { 'core' } \\ \text { b. ginnə } & \text { gini } & \text { 'fire' } \\ \text { c. wattə } & \text { watu } & \text { 'estate' } \\ \text { d. reddə } & \text { redi } & \text { 'cloth' }\end{array}$

Further data in (19) support the phonemic status of prenasalized consonants. As seen in (19), the nouns belonging to the same class exhibit heterosyllablic NCs in the singular and prenasalized consonants in the plural. Consider the data from Feinstein (1979).

(19) Inanimate Definite Nouns

$\begin{array}{lllll}\text { Singular } & & \text { Plural } & & \text { Gloss } \\ \text { a. kandə } & {[\text { kan.də] }} & \text { kandu } & {\left[\text { ka. }{ }^{n} \text { du }\right]} & \text { 'hill' } \\ \text { b. hombə } & {[\text { hom.bə] }} & \text { hombu } & {\left[\text { ho. }{ }^{\mathrm{b}} \mathrm{bu}\right]} & \text { 'chin' } \\ \text { c. hændə } & {[\text { hæn.də] }} & \text { hændi } & {\left[\text { hæ. }{ }^{\mathrm{n}} \mathrm{di}\right]} & \text { 'spoon' } \\ \text { d. kondə } & {[\text { kon.də] }} & \text { kondu } & {\left[\text { ko. }{ }^{\mathrm{n}} \mathrm{du}\right]} & \text { 'backbone' }\end{array}$

${ }^{11}$ The singular nouns suffix $-a$ is weakened into a schwa (Feinstein 1979).

${ }^{12}$ In the plurals, the final vowel alternations between [u] and [i] before back vowels and front vowels, respectively, are also found. There are other patterns for the plural in this language. The common pattern is a bare root surface as the plural as in mala 'flower,' mal 'flowers.' Some inanimates take the suffix /-wal/ in the plural as in kadəwal 'carrying poles' (kada 'carrying pole'). 
Therefore, unlike languages with prenasalized consonants derived from two segments, Sinhalese, being phonemic as a single segment, has a phonological category of prenasalized consonants. Additionally, prenasalized consonants do not change the moraicity of the preceding syllable. Therefore, this paper suggests that Sinhalese is a Type II language in which prenasalized consonants, as single segments, behave phonemic.

Sri Lanka Malay, an Austronesian language evolved through intimate contact of Malay with the dominant languages of Sinhalese and Tamil, developed prenasalized consonants. Most of heterosyllabic NC sequences in Standard Malay became tautosyllabic and syllabified as an onset. This is seen in (20).

(20) Prenasalized Consonants in Sri Lanka Malay ${ }^{13}$
a. [ga:. ${ }^{\mathrm{m}}$ bar]
'picture' $<$
b. [ta:. $\left.{ }^{n} \mathrm{dak}\right]$
'dance' $<$ 'tandak
c. $\left[\mathrm{ba}:{ }^{\mathrm{n}} \exists \mathrm{r}\right]$
'flood' $<$ "banjir

This paper assumes that the lengthening of the vowel in the first syllable is not due to the prenasalization, but the well-known vowel lengthening in Sri Lanka Malay where full vowels are predictably lengthened in open penultimate syllables.

However, loanwords from Tamil show the heterosyllabic behavior of NC sequences.

(21) NC Clusters in Loanwords in Sri Lanka Malay
a. [kañ.łi]
'groats'
$<$
Tamil kanji
b. [bañ.qu] 'insect' <
Tamil bandu
c. [tuñ.qu] 'piece'
$<$
Tamil tundu

13 This paper assumes that lengthening of the vowel in the first syllable is not due to the prenasalization, but the well-known vowel lengthening in Sri Lanka Malay wherein full vowels are predictably lengthened in open penultimate syllables. 
The data in (21c) can be contrasted with (20b) [tu:. " $\mathrm{duk}$ ] 'bend, bow,' which contains prenasalized consonants. Based on these data, this paper proposes that the phonology of a source language affects the realization of prenasalization.

\section{Prenasalized Consonants in Optimality Theory}

Given the various realizations of the NC sequences, this paper assumes that the edge-based constraints in Optimality Theory (McCarthy \& Prince 1993, 1999) can account for the prosodymorphology interface with respect to prenasalized consonants. Before analyzing a nature of prenasalized consonants, the languages investigated in this paper are categorized based on their types.

(22) Classification of Languages

\begin{tabular}{|c|l|}
\hline Type & Name of languages \\
\hline I & Fujian, Southern Barasan, Alawa, Sinhalese \\
\hline II & $\begin{array}{l}\text { Kikuyu, Kilega, Luganda, Nganasan, Terena, Land Dayak, } \\
\text { Apinayé, Sri Lanka, Malay }\end{array}$ \\
\hline III & Japanese \\
\hline IV & Tok Pisin, Diola-Fogny, Yidin \\
\hline
\end{tabular}

Referring to the Richness of the Base (Prince \& Smolensky 1993: 191) in Optimality Theory, this paper suggests that prenasalized consonants are underlyingly represented as nasal-consonant sequences no matter whether they are derived or phonemic. Then, the reranking of constraints induces the different realizations of prenasalized consonants.

(23) Richness of the Base (Prince \& Smolensky 1993: 191)

The source of all systematic cross-linguistic variation is constraint reranking. In particular, the set of inputs to the 
grammars of all languages is the same. The grammatical inventories of a language are the outputs which emerge from the grammar when it is fed the universal set of all possible inputs.

Therefore, the richness of the base requires that differences in prenasalized consonants in the phonological inventory arise from different constraint rankings, not different inputs. In this paradigm, when ${ }^{*}$ CODA dominates alignment constraints such as ${ }^{*}$ Complex, Uniformity, prenasalized consonants are achieved, while the reverse ranking is active in languages allowing NC clusters across a syllable boundary. The relevant constraints are given in (24).

(24) Constraints (Kager 1999)

a. Aling-Root-Left

The left edge of a root coincides with the left edge of a syllable.

b. * Coda

No coda is allowed.

c. ${ }^{*}$ Complex

No complex segments linked to a single root are allowed.

d. Uniformity

No element of the output has multiple correspondents in the input. (No unitary prenasalized consonants derived from two underlying segments.)

This paper proposes an amended version of constraint Uniformity in a way that a unitary prenasalized consonant $\left({ }^{\mathrm{N}} \mathrm{C}_{12}\right)$ incurs a violation of this constraint since it is fused into a single segment from two different underlying segments, while a complex prenasalized consonants $\left({ }^{\mathrm{N} 1} \mathrm{C}_{2}\right)$ does not due to the fact that still the underlying nasal and a consonant are separable. This is seen in the diagram in (25). 
(25) Correspondence Diagram for a Unitary and Complex Prenasalized Consonant

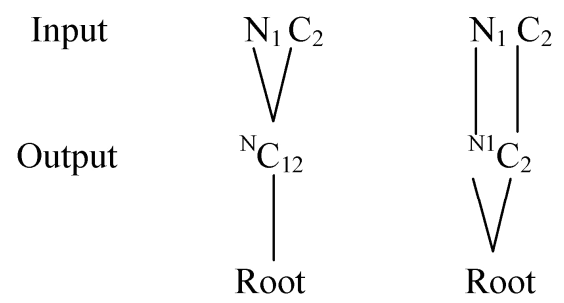

Violation Uniformity $\quad{ }^{*}$ Complex

Given the diagram in (25), the data in Sinhalese, which is assumed to have underlying phonemic and derived prenasalized consonants, are examined in (27) along with the constraint ranking in Sinhalese shown in (26).

(26) Constraint Ranking in Sinhalese *VV, Max, Max- $\mu$, Dep $>>{ }^{*}$ Coda $>>{ }^{*}$ Complex $>>$ Uniformity

(27) kandu $\rightarrow$ [ka. $\left.{ }^{\mathrm{n}} \mathrm{du}\right]$ 'hill' (pl)

\begin{tabular}{|c|c|c|c|c|c|c|c|}
\hline $\operatorname{kan}_{1} \cdot \mathrm{d}_{2} \mathrm{u}$ & ${ }^{*} \mathrm{VV}$ & $\operatorname{Max}$ & Max- $\mu$ & Dep & ${ }^{*} \mathrm{Coda}$ & ${ }^{*} \mathrm{Com}$ & UF \\
\hline a. ka. ${ }^{n} d_{12} \partial$ & & & & & & & $*$ \\
\hline b. ka. ${ }^{\mathrm{n} 1} \mathrm{~d}_{2} \partial$ & & & & & & $* !$ & \\
\hline c. $\operatorname{kan}_{1} \cdot \mathrm{d}_{2} \partial$ & & & & & $* !$ & & \\
\hline d. kaa. ${ }^{n} d_{12} \partial$ & $* !$ & & & & & & \\
\hline e. ka.n $n_{1} \dot{i} \cdot d_{2} \partial$ & & & & $* !$ & & & \\
\hline f. ka.d $d_{2} \partial$ & & $* !$ & & & & & \\
\hline
\end{tabular}

The candidate in (27a) is selected as an optimal form even though it violates Uniformity, banning a unitary prenasalized consonant, since the competitive candidate (27b) disobeys a higher 
ranked constraint ${ }^{*}$ Complex. Candidates (27c), (27d), (27e), and (27f) cannot be the winner because of an incurrence of ${ }^{*} \mathrm{Coda},{ }^{*} \mathrm{VV}$, Dep, and Max, respectively.

In contrast, as for the singular form of /kandə/ 'hill' $\rightarrow$ [kan.də], the nasal is syllabified as a coda of the preceding syllable and the consonant as an onset of the following syllable instead of deriving a prenasalized consonant. To account for this, this paper assumes that the singular morpheme in this language is a mora, which should be attached to a consonant, resulting in a moraic consonant, either a geminate or coda consonant. Consider the evaluation in (28).

(28) $/$ kandə/ $\rightarrow$ [kan.də] 'hill' (sg)

\begin{tabular}{|c|c|c|c|c|c|c|c|}
\hline$\left.\right|_{\mu} ^{\operatorname{kan}_{1} \cdot \mathrm{d}_{2} \partial+\mathrm{C}_{\text {singular }}}$ & ${ }^{*} \mathrm{VV}$ & Max & $\operatorname{Max}-\mu$ & Dep & ${ }^{*}$ Coda & ${ }^{*} \mathrm{Com}$ & UF \\
\hline a. ka. ${ }^{n} d_{12} \curvearrowright$ & & & $* !$ & & & & $*$ \\
\hline b. ka. ${ }^{\mathrm{n} 1} \mathrm{~d}_{2} \partial$ & & & $* !$ & & & * & \\
\hline c. $\mathrm{kan}_{1} \cdot \mathrm{d}_{2} ə$ & & & & & $*$ & & \\
\hline d. kaa. ${ }^{n} d_{12} ə$ & $* !$ & & & & & & \\
\hline e. ka.n $n_{1} \dot{i} \cdot d_{2} \partial$ & & & & $* !$ & & & $*$ \\
\hline f. ka.d $d_{2} ə$ & & $* !$ & & & & & \\
\hline
\end{tabular}

Candidates (28a) and (28b) do violate Max since a mora linked with a consonant is not realized in the surface; candidate (28c) displaying a coda consonant is chosen as the winner since a coda consonant is treated as linked to a mora by Weight-by-Position (Hayes 1989). Candidate (28d) is left out because of a long vowel; (28e) cannot be the optimal form due to the epenthetic vowel between a nasal and a consonant. Then, candidate (28f) is a loser because of the deletion of a nasal, violating Max. 
The evidence from Bantu languages argues against an analysis of ${ }^{\mathrm{N}} \mathrm{Cs}$ as simple units in underlying as well as surface representation. While some languages such as Sinhalese may be analyzed in terms of the same classification of nasal and consonant in the underlying representation as well as in the surface representation, it is clear that such conclusions should not be adopted in the case of Bantu languages. To account for a sequence of a syllabic nasal and an onset consonant, constraint Align-Root-Left is proposed. Examine the Luganda data with its constraint ranking.

(29) Constraint Ranking in Luganda

Align-Root-Left, Max, Dep, ${ }^{*}$ Coda, ${ }^{*}$ Complex $>>$ Uniformity, ${ }^{*} \mathrm{VV}$

(30) $/ \mathrm{N}-\mathrm{kuba} / \rightarrow$ [n.ku.ba] 'rain'

\begin{tabular}{|c|c|c|c|}
\hline$\left.\right|_{\mu} ^{\mathrm{N}_{1} \cdot \mathrm{k}_{2} \mathrm{u} \cdot \mathrm{ba}}$ & AL-Root-L & Max- $\mu$ Dep ${ }^{*}$ Coda ${ }^{*}$ Com & UF ${ }^{*} \mathrm{VV}$ \\
\hline a. $\eta_{1}, k_{2} u \cdot b a$ & & i & $*$ \\
\hline b. ${ }^{n 1} \mathrm{k}_{2}$ u.ba & $* !$ & * & \\
\hline c. ${ }^{n} k_{12}$ u.ba & *! & $*$ & \\
\hline
\end{tabular}

Undominated constraint Align-Root-Left rules out any candidate with prenasalized consonants derived from a morphemic nasal and a root-initial consonant, as in (30b) and (30c), at the expense of a violation of Uniformity as in (30a). The root internal nasal and consonant sequences result in prenasalized consonants triggering vowel lengthening. This is seen in (31). 
(31) $/$ ku-lind-a/ $\rightarrow$ [ku.lii. ${ }^{\text {nda }}$ ' 'to wait'

\begin{tabular}{|c|c|c|c|c|c|c|c|}
\hline$\left.\right|_{\mu} ^{\operatorname{ku} . \operatorname{lin}_{1} \cdot \mathrm{d}_{2} \mathrm{a}}$ & AL-Root-L & Max- $\mu$ & Dep & Coda & ${ }^{*} \mathrm{Com}$ & UF & $* \mathrm{VV}$ \\
\hline a. ku.li. ${ }^{n} d_{12} a$ & & *! & & & & * & \\
\hline b. ku.li. ${ }^{n 1} d_{2} a$ & & $* !$ & & & * & & \\
\hline c. ku.lii. ${ }^{n} d_{12} a$ & & & & & & $*$ & $*$ \\
\hline d. ku. $\operatorname{lin}_{1} \cdot \mathrm{d}_{2} \mathrm{a}$ & & & 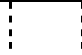 & $* !$ & & & \\
\hline
\end{tabular}

By Weight-by-Position (Hayes 1989), coda consonant in Luganda is moraic; any candidate undergoing deletion of a mora is doomed to be ruled out. Therefore, candidates (31a) and (31b) can never be optimal. 'Coda dominates Uniformity; (31c) is selected as the winner, while (31d) is not since (31d) violates the higher-ranked constraint *Coda.

Toward the analysis of prenasalized consonants in the Tohoku dialects in Japanese, this paper adopts a different approach from previous research. First, this paper suggests that a nasal is posited in the input; the input of [han da] 'skin' is /handa/, not /hada/. Second, it is proposed that there are two types of nasals in this language: a moraic coda nasal that surfaces as a coda consonant and a nonmoraic nasal that is realized as part of prenasalized consonants. The constraint ranking in this language is shown in (32).

(32) Constraint Ranking in the Tohoku Dialects in Japanese Align-Root-Left, Max- $\mu$, Dep, ${ }^{*} \mathrm{VV}>>{ }^{*}$ Coda, Uniformity $>{ }^{*}$ Complex

The evaluations of [ha. ${ }^{\text {nda] }}$ 'skin' and [hon.to] 'real' are examined in (33) and (34), respectively. 
(33) /handa/ $\rightarrow$ [ha. "da] " $[$ han.da] 'skin'

\begin{tabular}{|c|c|c|c|c|c|c|}
\hline $\operatorname{han}_{1} \mathrm{~d}_{2} \mathrm{a}$ & AL-Root-L & Max- $\mu$ & Dep: 'VV & ${ }^{*}$ Coda & $\begin{array}{c:c}\mathrm{UH} \\
\mathrm{a}\end{array}$ & ${ }^{*} \mathrm{Com}$ \\
\hline a. ha. ${ }^{n} d_{12} a$ & & 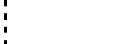 & ? & & $* !$ & \\
\hline b. ha. ${ }^{\mathrm{n} 1} \mathrm{~d}_{2} \mathrm{a}$ & & 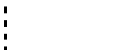 & $\vdots$ & & & * \\
\hline c. $\operatorname{han}_{1} \cdot \mathrm{d}_{2} \mathrm{a}$ & & 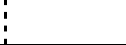 & ? & $* !$ & & \\
\hline d. haa. ${ }^{n} d_{12} a$ & & ? & $* !$ & & ! & \\
\hline
\end{tabular}

(34) /hon.tou/ $\rightarrow$ [hon,to] 'real'

\begin{tabular}{|c|c|c|c|c|c|c|}
\hline$\left.\right|_{\mu} ^{\operatorname{han}_{1} \mathrm{~d}_{2} \mathrm{a}}$ & AL-Root-L & Max- $\mu$ & Dep *VV & ${ }^{*}$ Coda & & ${ }^{*} \mathrm{Com}$ \\
\hline a. ha. ${ }^{n} d_{12}$ a & & $* !$ & & & * & \\
\hline b. ha. ${ }^{n 1} d_{2} a$ & & $* !$ & & & & * \\
\hline c. han $1 \cdot \mathrm{d}_{2} \mathrm{a}$ & & & & * & & \\
\hline d. haa. ${ }^{n} d_{12} a$ & & & $* !$ & & & \\
\hline
\end{tabular}

The difference on the moraic status of a coda nasal is attributed to the realization of prenasalized consonants. As shown in tableau (33), ${ }^{*}$ Complex is a lowest-ranked constraint; the candidate in (33b) turns into a winner. However, in tableau (34), due to the fact that Max- $\mu$ and *V are undominated, any candidates that are unfaithful to these constraints are ruled out: (34c) turns out to be an optimal form.

Southern Barasano selects another strategy to accomplish prenasalized consonants. By adopting Pigott's (1992) articulatory enhance approach, this paper proposes undominated constraints: Identity-[voice] and ${ }^{*}$ Stop [+voiced]. Markedness constraint ${ }^{*}$ Stop $_{[+ \text {voiced] }}$ is stimulated by nasal leakage (Pigott 1992) enhanced by spontaneous voicing. The simplified constraint ranking in this language is provided in (35). 
(35) Constraint Ranking in Southern Barasano Identity-[voice], ${ }^{*}$ Stop ${ }_{[+ \text {voice }},{ }^{*}$ Complex $>>$ Uniformity, Dep

(36) $/$ bago/ $\rightarrow\left[{ }^{\mathrm{m}} \mathrm{ba}^{\mathrm{n}} \mathrm{go}\right]$ 'eater'

\begin{tabular}{|c|c|c|c|c|c|}
\hline $\mathrm{b}_{1} \mathrm{ag}_{2} \mathrm{O}$ & $\begin{array}{l}\text { Ident- } \\
\text { [voice] }\end{array}$ & ${ }^{*}$ Stop $_{[+\mathrm{v}]}$ & ${ }^{*} \mathrm{Com}$ & UF & Dep \\
\hline a. ba.go & & $* * !$ & & & \\
\hline b. ${ }^{\mathrm{m}} \mathrm{b}_{1}$ a. ${ }^{n} \mathrm{~g}_{2} \mathrm{O}$ & & & & $*$ & $*$ \\
\hline c. ${ }^{\mathrm{m} 3} \mathrm{~b}_{1} \mathrm{a} \cdot{ }^{\mathrm{n}}{ }^{4} \mathrm{~g}_{2} \mathrm{O}$ & \multirow[b]{2}{*}{$* * !$} & & \multirow[t]{2}{*}{$* !$} & & $*$ \\
\hline d. $\mathrm{t}_{1}$ a. $\mathrm{k}_{2} \mathrm{O}$ & & & & & \\
\hline
\end{tabular}

By undominated Identity-[voice] and ${ }^{*}$ Stop $[+$ voiced], candidates cannot have either voiced stops or voiceless stops derived from voiced stops to be chosen as a winner. Also, a violation of ${ }^{*}$ Complex ends up being left out is since they are outranked over Uniformity and Dep.

\section{Conclusions}

This paper investigates the data of prenasalized consonants from the perspective of typology and then categorizes languages into four types: phonemic prenasalized consonants, derived prenasalized consonants functioning as a unitary segment, derived prenasalized consonants behaving as a complex segment, and phonetically or articulatory enhanced prenasalized consonants.

Furthermore, within Optimality Theory, this paper argues that diverse patterns of prenasalized consonants are in fact attributable to a re-ranking of universal constraints rather than different inputs by proposing a single underlying representation $\mathrm{NC}$. 


\section{References}

Anderson, S. 1976. Nasal Consonants and the Internal Structure of Segments. Language 52.2, 326-344.

Arnott, D. 1970. The Nominal and Verbal Systems of Fula. London: Oxford University Press.

Brownman, C. \& L. Goldsten. 1986. Towards an Articulatory Phonology. Phonology Yearbook 3, 219-252.

Bruhn, D. 2006. The Phonetic Inventory of Mong Leng. The Linguistic 110 Project. University of California, Berkeley.

Burgess, E. \& P. Ham. 1968. Mutilevel Conditioning of Phoneme Variants in Apinayé. Linguistics 41, 5-18.

Chomsky, N. \& M. Halle. 1968. The Sound Pattern of English. New York: Harper \& Row Publishers.

Coffman, I. 2008. Antihomorganicity in Apinayé and Hayu: Evidence for Closure Duration as a Phonotactic Variable. UC Berkeley Phonology Lab Annual Report 188-224.

Cole, J. \& C. Kisseberth. 1994. Nasal Harmony in Optimal Domain Theory. Ms., University of Illinois, Urbana-Champaign. . 1995. Paradoxical Strength Condition in Harmony

Systems. In J. Beckman (ed.), Proceedings of the $25^{\text {th }}$ Annual Meeting of the North East Linguistic Society 17-29. Amherst, MA: GLSA.

Dixon, R. 1977. A Grammar of Yidin ${ }^{y}$. Cambridge: Cambridge University Press.

Evans, N. 1995. Current Issues in the Phonology of Australian Languages. In J. Goldsmith (ed.), The Handbook of Phonological Theory 798-816. Cambridge, MA: Blackwell Publishers Ltd.

Feinstein, M. 1979. Prenasalization and Syllable Structure. Linguistic Inquiry 10.2, 245-278.

Gudschinsky, S. et al. 1970. Native Reaction and Phonetic Similarity in Maxakali Phonology. Language 46, 77-88.

Ham, P. 1961. Apinayé Grammar. Brasilia: SIL-AL-108. 
Harris, J. 1969. Spanish Phonology. Cambridge, MA: MIT Press. Hayes, B. 1989. Compensatory Lengthening in Moraic Phonology. Linguistic Inquiry 20.2, 253-306.

. 1991. Metrical Stress Theory: Principles and Case Studies. Ms., University of California, Los Angeles.

Herbert, R. 1975. Reanalyzing Prenasalized Consonants. Studies in African Linguistics 6.2, 105-123.

. 1977. Phonetic Analysis in Phonological Description: Prenasalized Consonants and Meinhof's Rule. Lingua 43, 339373.

. 1986. Language Universals, Markedness Theory, and Natural Phonetic Processes. Berlin: Mouton de Gruyter.

Hubbard, K. 1995a. Morafication and Syllabification in Bantu Languages. Journal of African Language and Linguistics 16, 137-155.

. 1995b. Prenasalized Consonants and Syllable Timing: Evidence from Runyambo and Luganda. Phonology 12, 235256.

Hyman, L. 1992. Moraic Mismatch in Bantu. Phonology 9, 255-265. Hyman, L. \& A. Ngunga. 1997. Two Kinds of Moraic Nasals in Ciyao. Studies in African Linguistics 26, 131-163.

Kager, R. 1999. Optimality Theory. Cambridge: Cambridge University Press.

Kanai, Y. 1982. A Case against the Morphophonemic-Allophonic Principle. Linguistic Inquiry 13, 320-323.

Ladefoged, P. \& I. Maddieson. 1996. The Sounds of the World's Languages. Cambridge, MA: Blackwell Publishers Ltd.

Maddieson, I. 1989. Prenasalized Stops and Speech Timing. Journal of the International Phonetic Association 19.2, 57-66.

McCarthy, J. \& A. Prince. 1993. Prosodic Morphology I: Constraint Interaction and Satisfaction. Ms., University of Massachusetts \& Rutgers University. . 1999. Faithfulness and Identity in Prosodic Morphology. 
In R. Kager et al. (eds.), The Prosody-Morphology Interface 218-309. Cambridge: Cambridge University Press.

Milner, G. 1956. Fijian Grammar. Suva: Government Press.

Nash, D. 1979. Yidin ${ }^{\mathrm{y}}$ Stress: A Metrical Account. In E. Battistella (ed.), Proceedings of the $9^{\text {th }}$ Annual of the North East Linguistics Society, CUNY Forum 112-130. New York: Queens College Press.

Odden, D. 1996. The Phonology and Morphology of Kimatuumbi. Oxford: Clarendon Press.

Piggott, G. 1992. Variability in Feature Dependency: The Case of Nasality. Natural Language and Linguistic Theory 10, 33-78.

Prince, A. \& P. Smolensky. 1993. Optimality Theory: Constraint Interaction in Generative Grammar. Ms., University of Colorado.

Rivas, A. 1974. Nasalization in Guarani. Papers from the $5^{\text {th }}$ Annual Meeting of the North Eastern Linguistic Society 134-143.

Ruhlen, M. 1987. A Guide to the World's Languages. Stanford, CA: Stanford University Press.

Scott, N. 1964. Nasal Consonants in Land Dayak. In D. Abercrombie et al. (eds.), Honor of Daniel Jones. London: Longman.

Tak, J-Y. 2006. Typological Analysis on Two Types of Prenasalized Consonants $\left({ }^{\mathrm{N}} \mathrm{C}\right)$ in Bantu: Their Moraic Representations. Korean Journal of Linguistics 31.3, 463-493.

Termes, E. 1986. A Grammatical Hierarchy of Joining. In H. Anderson (ed.), Trends in Linguistics: Sandhi Phenomena in the Languages in Europe 11-22. Berlin: Mouton de Gruyter.

Vaysman, O. 2009. Segmental Alternations and Metrical Theory. Ph.D Dissertation. Cornell University.

Welmers, W. 1978. African Language Structures. Berkeley, CA: University of California Press.

Wiswall, W. 1989. Fula Consonant Gradation: In Support of Radical Underspecification. Proceedings of the West Coast Conference on Formal Linguistics 429-444.

Yamane-Tanaka, N. 2005. The Implicational Distribution of 
158 Universals of Prenasalized Consonants

Prenasalized Stops in Japanese. In J. van de Weijer et al. (eds.), Voicing in Japanese 123-156. Berlin: Walter de Gruyter. 